\title{
Partnership in Practice: Implementing Healey's Conceptual Model
}

\author{
Arshad Ahmad ${ }^{a}$, Aadil Ali ${ }^{b}$, John VanMaaren ${ }^{a}$, Janette Barrington a , Olivia Merritt ${ }^{\text {, }}$, and \\ Kyle Ansilio ${ }^{a}$
}

a Paul R. MacPherson Institute for Leadership, McMaster University, Hamilton, Canada.

${ }^{b}$ Faculty of Medicine, University of Toronto, Toronto, Canada.

' Department of Psychology, University of Waterloo, Waterloo, Canada

Contact: $\underline{\text { arshad@mcmaster.ca }}$

\section{ABSTRACT}

This case study discusses the implementation of Healey, Flint, and Harrington's (2014) model of student engagement through partnership with staff. Healey et al. (2014) identify issues associated with "putting partnership into practice" including inclusivity and scale, power relations, reward and recognition, transition and sustainability, and identity. Faculty, staff, and students participating in a Students as Partners (SaP) Program at McMaster University's MacPherson Institute encountered these issues during a Scholarship of Teaching and Learning (SOTL) project. This paper explores our reflections and suggests refinements related to the above five issues. It concludes by identifying possible new directions for SaP programs.

\section{KEYWORDS}

students as partners, scholarship of teaching and learning, conceptual model, power, identity, student engagement

The educational benefits of Students as Partners (SaP) working in reciprocal relationships with faculty and staff can be traced back to the work of John Dewey (1939). The benefits of SaP can also be traced to social constructivism (Lave \& Wenger, 1991; Wenger, 1998), which sees learning as a process that occurs through individual experience and reflection and through collective learning and negotiation. While student-staff partnerships are not new, they have gained widespread recognition for promoting student engagement (Kuh, 2010), enhancing research skills (Jarvis, Dickerson, \& Stockwell, 2014), and transforming student and staff approaches to teaching and learning (Cook-Sather, Bovill, \& Felten, 2014). SaP programs 
have been championed by leading scholars in Europe, North America, and Asia (Bovil \& Bulley, 2011; Felten et al., 2013; Healey, Flint, \& Harrington, 2014). In fact, several regional, national, and international conferences have featured scholarship on SaP programs. For example, at the 2017 RAISE (Researchng, Advancing, and Inspiring Student Engagement) conference in Birmingham, Cook-Sather outlined how theory informs conceptualizations of student-staff partnerships. Despite the momentum of SaP programs, they are relatively nascent, making reflection on student and staff experiences working in partnership vital to enriching SaP programs.

McMaster University in Canada is home to a pioneering and internationally recognized SaP program. McMaster's SaP program has grown from a handful of students in 2013 to over 80 students engaged in partnerships across the university in 2017. This commitment to SaP appears both in the institutional mission (Deane, 2014) and in the 2015 strategic plan of the McMaster Institute for Innovation and Excellence in Teaching and Learning (MIIETL), recently renamed the Paul R. MacPherson Institute for Leadership, Innovation, and Excellence in Teaching.

The implementation of the SaP program at McMaster was based on Healey, Flint, and Harrington's (2014) model of student engagement through partnership (see Figure 1). This model outlines four ways students and staff can engage in partnership learning communities: assessment projects, curriculum consultation, subject-based research, and SoTL. An updated version of this model is adopted by the Higher Education Academy (2015, in Healey et al., 2016); however, the theory-to-practice issues are addressed only in the 2014 model.

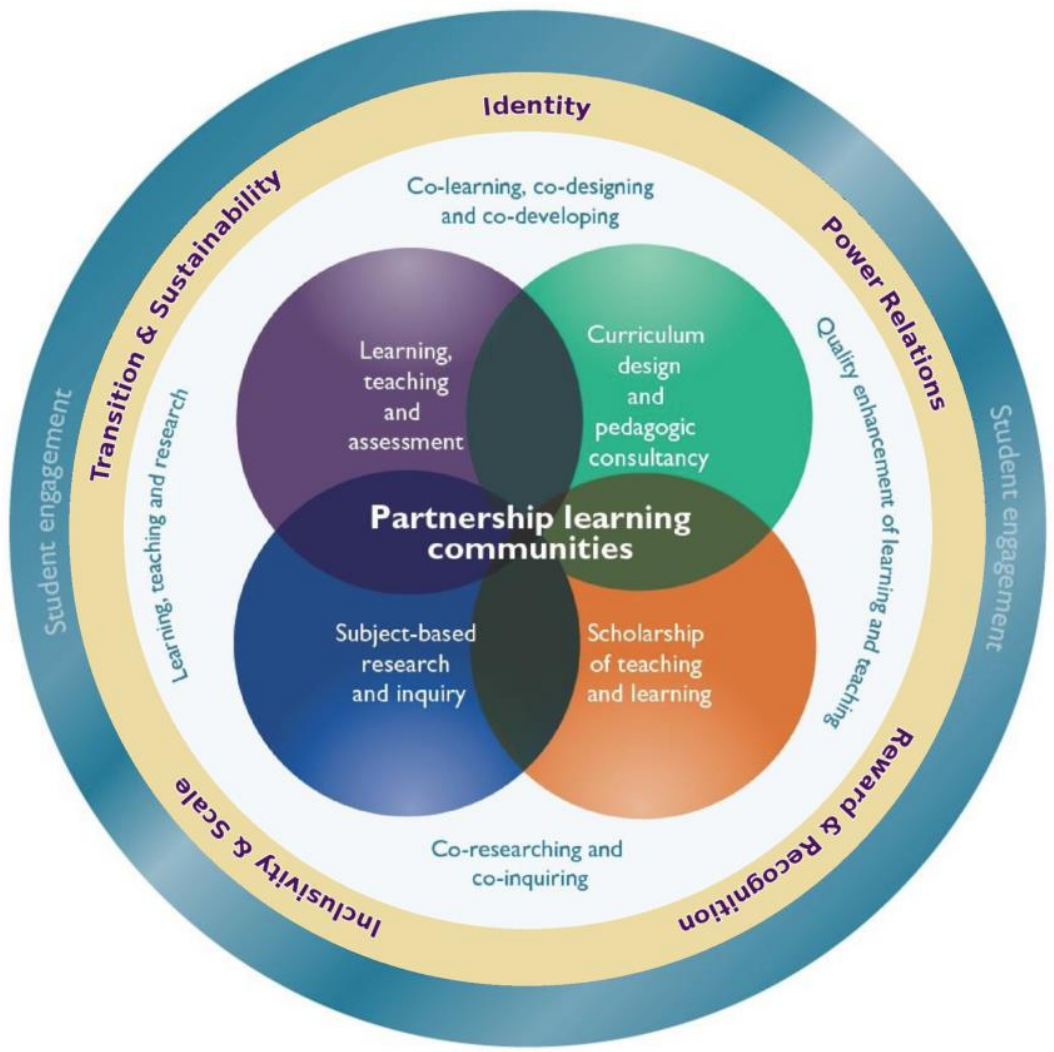

Figure 1: The Healey et al. student partnership model (Healey, Flint, \& Harrington, 2014, p. 25) enhanced with issues related to putting partnership into practice

Ahmad, A., Ali, A., VanMaaren, J., Barrington, J., Merritt, O., \& Ansilio, K.(2017) Partnership in Practice? Implementing Healey's Conceptual Model International Journal for Students as Partners 1(2) 


\section{THE PARTNERS AND THE RESEARCH PROJECT}

The core research team is made up of the contributors to this case study. The team consists of individuals who bring diverse levels of education and disciplinary approaches to the research, as shown in Table 1.

Table 1. The core SaP team

\begin{tabular}{|l|l|}
\hline \multicolumn{1}{|c|}{ TITLE } & \multicolumn{1}{c|}{ DISCIPLINE } \\
\hline Undergraduate student (now graduate student) & Psychology, Neuroscience, \& Behavior \\
\hline Undergraduate student (now graduate student) & Molecular Biology \& Genetics \\
\hline Undergraduate student (now graduate student) & Engineering Physics \\
\hline $4^{\text {th }}$-year PhD Candidate & Religious Studies \\
\hline Professor, Vice-Provost, Teaching \& Learning & Business/Education \\
\hline Associate Director, Educational Development & Education \\
\hline Director, Centre for Teaching \& Learning & Psychology/Cognitive Science \\
\hline Professor Emeritus & Neuroscience \& Biostatistics \\
\hline Professor Emeritus & Psychology/Pedagogy \\
\hline
\end{tabular}

The partners collaborated on a SoTL project titled Student Perceptions of Teaching (SPOT). This three-year research project was undertaken as part of the MacPherson Institute, and all six partners participated through different associations with the MacPherson Institute. The project compared teacher self-reported data with student and observer data on teaching practice. The specific aims of the study were to investigate the psychometric properties of a learner-centered measure while examining the relationship between this variable and student performance.

\section{METHODOLOGY}

This "intrinsic" case study (Stake, 1995) addresses the theory-to-practice continuum through an ongoing SoTL research project. In describing and analyzing working together in this partnership project, this case study has engaged in a collaborative writing process (Ede \& Lunsdord, 1990) that included four phases: (a) initial discussion to identify the main goal and issues; (b) general discussion of the strengths and weaknesses of our collective experience; (c) preparation of a first draft by one member followed by individual contributions from all; and (d) integration of theory, comments, and reactions resulting in refinement of the paper. Core members (both past and present) were invited to be co-authors and contribute to each section of the paper. Retrospective analysis was used to capture evidence according to existing theoretical frameworks.

\section{PUTTING PARTNERSHIP INTO PRACTICE}

The SPOT research experience provides valuable insight for further refining SaP models. Healey et al. (2014) identify five issues related to putting partnership into practice: inclusivity and scale, power relations, reward and recognition, transition and sustainability, and identity. These five issues structure the following discussion of student and staff experiences as reciprocal partners.

Ahmad, A., Ali, A., VanMaaren, J., Barrington, J., Merritt, O., \& Ansilio, K.(2017) Partnership in Practice? Implementing Healey's Conceptual Model International Journal for Students as Partners 1(2) 


\section{Issues of inclusivity and scale}

Finding a balance between inclusivity and scale is the first challenge for putting partnerships into practice. In particular, the ideal of equal opportunity that would enable every student to participate at the highest level of her/his ability (Hart, 1992) is limited by the constraints of specific partnerships. Healey et al. (2014) emphasize that where selecting partners is unavoidable, the selection criteria must be clear and must consciously counteract creating an "elite" partnership of those already "best-served" by the system (Rudduck \& Fielding, 2006), or of those with the "cultural capital" enabling expected contributions (Taylor, 2009).

At McMaster, opportunities in the SaP program are advertised each semester university-wide. When applying, students select their top three projects and provide a statement of interest for each project. Project leaders review candidates against criteria pertinent to each project and interview short-listed candidates. The selection process for the SPOT project valued students who indicated the project was their first choice, demonstrated a high level of interest in research on teaching and learning, and had prior experience in statistical analysis.

The scale of the SPOT research project enabled the project to select two student partners per year. Having multiple student partners brought different student perspectives to the project and provided a student-staff balance in the core research group.

\section{Issues of power relations}

Simply put, partnership means sharing power. Shared power means being co-creators and co-decision makers (Hart, 1992). Healey et al. (2014) emphasize that in practice, power distribution fluctuates over the course of the relationship. It is also important to be honest about contexts where a significant distribution of power is not possible due to experience and expertise gaps between partners (Bovill \& Bulley, 2011). Healey et al. (2014) further caution against structures that may reinforce existing inequalities and are counterproductive to partnerships. In particular, student partners are accustomed to traditional student-staff hierarchies in their university experience (Hutchings, Bartholomew, \& Reilly, 2013). Further, the SaP model itself embeds a power imbalance that assumes staff bestow power upon students. However, the model does not address power differences between students or between staff (Taylor, 2009).

The experience of student and staff partners in the SPOT project reflects key issues related to shared power. Specific ways in which staff relinquished a level of control in the SPOT project included involving students in facilitating meetings, producing independent literature reviews, establishing contact with internationally known scholars, taking the lead in a studentstaff conference presentation, organizing data collection, creating online student surveys, and providing feedback that influenced study design and the re-evaluation of project direction. Students felt initial discomfort with the degree of autonomy and responsibility, especially due to experience and knowledge gaps between themselves and staff partners. Staff felt confident about the students' ability and their capacity to assume responsibility, while remaining sensitive to supporting student learning.

On the one hand, the SPOT research team saw the embedded faculty and staff/student power imbalance as unavoidable, because the initiative for student partnership comes from

Ahmad, A., Ali, A., VanMaaren, J., Barrington, J., Merritt, O., \& Ansilio, K.(2017) Partnership in Practice4 Implementing Healey's Conceptual Model International Journal for Students as Partners 1(2) 
faculty and staff, who must bestow power on students. On the other hand, additional preexisting institutional power differences, such as different levels of education between students or different university roles between faculty and staff, turned out to be less consequential for group power distribution than merit. For students, confidence became a primary cause for the distribution of power. Specific skill sets that individual students possessed, whether organizational, analytical, or compositional, also affected the distribution of power. Faculty and staff power dynamics, although complicated by the supervisory role of one member, benefitted significantly from a prior history of collaboration. The issue of power relations only came to the fore when an internationally known scholar was invited for consultation. Different faculty assumed incompatible power roles due to ideological differences that were grounded in different areas of expertise. This threatened to undermine the collaborative spirit of the team. Appealing to foundational values of SaP programs, especially role modeling, helped resolve differences and enabled the group to move beyond their respective power roles in order to work more collaboratively as partners.

In addition, an important example of power dynamics is how any group negotiates authorship and the issue of attributing credit. This became a source of tension given different expectations and disciplinary conventions. Some members of the group had strong views but agreed they were against tokenism and arbitrary conventions. Authorship was eventually based on merit weighted by the respective contribution of ideas, the actual writing of the article, and the visible pieces of collaborative work done. It is recommended that authorship criteria are discussed up front and revisited periodically as lead roles shift in the evolution of the partnership project (Fine \& Kurdek, 1993).

\section{Issues of reward and recognition}

A third issue related to putting partnership into practice is the system of incentives for both students and staff. This is a challenge because individuals engage in partnerships on different terms. Adequate support is especially needed when students are engaged outside of their core disciplines and when the partnership meets no credited educational objective. Healey et al. (2014) suggest providing formal documentation of skills developed during the partnership as a form of reward. In addition, payment for work completed can help alleviate the financial strain of post-secondary education (Robotham \& Julian, 2006). Healey et al. (2014) also note the importance of institutional incentives for staff to engage in partnerships, for example, in the appraisal process or in formal awards. Embedding the system of incentives in the institutional framework promotes a culture of partnership, while insufficient reward and recognition will negatively influence inclusivity and power relations among partners.

The SaP program at McMaster employs students as paid research partners, enabling students to include "student research partner" on their curricula vitae. Further, the program has yielded several conference presentations, publications in top-tier journals with students as co-authors (i.e. The International Journal for Academic Development and The Canadian Journal for Disability Studies), and the launch of the International Journal of Students as Partners, which is co-edited by students. While faculty and staff function as paid employees, they choose SaP projects based on personal interest. Engagement in scholarly projects in the SaP program also counts towards merit increases for staff of the MacPherson Institute in annual performance reviews.

Ahmad, A., Ali, A., VanMaaren, J., Barrington, J., Merritt, O., \& Ansilio, K.(2017) Partnership in Practice 5 Implementing Healey's Conceptual Model International Journal for Students as Partners 1(2) 
Student partners in the SPOT research project noted that both financial compensation and formal documentation of skills were instrumental for their initial interest. However, students mentioned two less tangible forms of reward and recognition: a chance to collaborate with established researchers and an interest in teaching and learning research. All students had expressed interest in the SPOT research topic directly due to either past teaching experience or future aspirations of teaching. Two students noted that collaboration created valuable professional contacts that opened new avenues for career goals. Thus, while the topic remained outside their core learning area, it directly related to career goals. Interestingly, it is these latter incentives that provided the primary motive for continued association with the SPOT research project. The strength of these less tangible incentives was demonstrated by the continued voluntary engagement of student partners when they were no longer officially paid student partners. The distinction between rewards and recognition related to initial interest and continuing motivation, and the different influences of intrinsic and extrinsic motivation for student partners are important areas for further refinement of SaP programs.

\section{Issues of transition and sustainability}

Another challenge for putting partnership into practice relates to the duration of a partnership. Students face the obstacle of having a time-bound relationship based on the semester system, and thus are less likely than staff to be engaged in partnerships for long periods of time. Healey et al. (2014) emphasize the time required for newcomers to fully integrate into a community and suggest developing strategies for providing new members access to the participative memory of the community and for initiating relationships between outgoing and incoming student partners (Summers, Pearson, Gough, \& Siekierski, 2013).

In order to smooth transitions and promote sustainability, the SaP program at McMaster created opportunities for students to continue for second and third semesters. Introductory sessions, periodic workshops, and a year-end symposium also provide comprehensive opportunities for strengthening student-staff partnerships.

Two of the three student partners whose affiliation with McMaster ended have continued to contribute to the SPOT project beyond their degree program. In this case, the partnership has transcended institutional affiliation. Multiple student partners highlighted the importance of a single staff contact person tasked with acclimatizing student partners. In meetings with this staff partner, students could practice operating with shared power before participating in full-team meetings. This role of coordinator was essential for ensuring appropriate tasks for each partner and overall inclusivity of each community member. Finally, the two students who joined in the third year of the project were tasked with an extensive literature review. The purpose of the literature review was to reevaluate the SPOT research direction, but it also streamlined students' acquisition of the participative memory of the community, thereby assisting in discussions and integration of the literature within the research group.

\section{Issues of identity}

Two aspects of identity relate to successful partnerships. First, students and staff enter partnership with multiple prior identities, and different identities may dominate in different contexts. Healey et al. (2014) also caution against over-simplifying partners as nothing but their roles as either students or staff. Second, student and staff identities change through

Ahmad, A., Ali, A., VanMaaren, J., Barrington, J., Merritt, O., \& Ansilio, K.(2017) Partnership in Practice 6 Implementing Healey's Conceptual Model International Journal for Students as Partners 1(2) 
participating in learning communities (Mcmillan \& Chavis, 1986). The blurred roles of partnership communities are especially fertile ground for transformed identities as students and staff become co-learners and co-researchers and may lead to the deconstruction of "student" and "staff" labels.

One student partner noted that participating in the SPOT study helped the student develop a stronger appreciation for teaching and learning. As an active teaching assistant, reading literature about best teaching practices enabled the student to further reflect on tutorial organization. Interestingly, the student partner formed partnership-like relations with their own students. Although the model makes no distinction between types of students, one student noted their unique identity within the "student" half of the staff/student dichotomy. As a PhD candidate, their main experience of graduate-undergraduate relations was as a TA with the institutionally embedded power roles marked by grading student work and leading tutorials. Joining this study allowed this student to partner with undergraduate students.

One student presented findings of the study at the Society for Teaching and Learning in Higher Education (STHLE) annual conference. This student described the experience as empowering and enhancing self-motivation for research. In addition, they noted that their work felt more significant after having the opportunity to share it with a broader audience. This experience was transformative for the student's perception of the overall importance of research.

Lastly, one student who was new to the study found it difficult to understand topics discussed by more experienced community members. Once "caught up" with the relevant literature, this student found it easier to integrate new knowledge and ultimately felt more comfortable during project-based roundtable discussions.

Staff partners emphasized the time needed to build SaP relationships and felt that SaP projects need to be envisioned beyond one semester. McDermott (1999) expresses this sentiment while discussing communities of practice: "To convey the depth of people's insights in a way that is valuable to others, learning needs to be an exchange in which people build enough relationship to understand and make sense of each other's ideas" (p. 8). Staff also expressed surprise at the level of student competence in every aspect of the research project and suggested that staff expectations of students may need to be raised. Indeed, this partnership experience repeatedly highlighted student adeptness for grasping educational literature regardless of academic background and for performing consequential tasks with increasing independence.

\section{NEW DIRECTIONS FOR SAP PROGRAMS}

The partnership experience of the SPOT research project demonstrates that Healey et al.'s (2014) theoretical model can be effectively put into practice. This section summarizes the above suggestions for improving the implementation of SaP programs, while also identifying new directions for further refinement.

First, the SPOT project underlined how pre-existing power dynamics between students, between staff, and between students and staff influence partnerships. Speaking openly about evolving power dynamics helped to redistribute power and re-energize work flow. When considering types of incentives, the distinctions between intrinsic and extrinsic motivation, and between initial interest and continued motivation, may be helpful. Some keys to successful

Ahmad, A., Ali, A., VanMaaren, J., Barrington, J., Merritt, O., \& Ansilio, K.(2017) Partnership in Practice? Implementing Healey's Conceptual Model International Journal for Students as Partners 1(2) 
partner transitions include a designated coordinator for onboarding new students and a literature review as an early task for student partners joining ongoing projects.

Beyond the issues raised by Healey et al. (2014) with respect to inclusivity, team members retrospectively felt the group adjusted well to a wide range of expertise. This speaks to a form of elasticity that comes from broadening the understanding of inclusivity to create space for new members to build on the work of those completing their terms so that long-term projects like ours (three years) can be sustained. Also, SaP programs at McMaster are mostly centralized through the MacPherson Institute, which limits how much these can be scaled. One way forward is to establish satellite SaP programs in different Faculties where dynamics may better enable the inclusion of more student partners.

The experience of the SPOT research team underscored the enhanced learning potential of SaP initiatives, which address strategic institutional priorities reflected in their distribution of resources. The crucial question of funding and sustaining SaP programs is best framed as either finding new funds, or as reallocating resources towards initiatives which demonstrate desired learning outcomes. Approached in this way, any institution that values student partnership can implement a SaP program.

In the end, institutional factors, while necessary for a successful SaP program, are not sufficient to guarantee program outcomes. Rather, it is the personal investment of each partner that ultimately makes each SaP project meaningful. Accordingly, SaP programs will thrive as partnership experience refines robust models like Healey et al.'s (2014) through rigorous reflection that highlights vulnerability within partnerships and also creates lasting bonds that strengthen learning for both student and staff partners.

\section{NOTE ON CONTRIBUTORS}

Arshad Ahmad is the Vice Provost, Teaching \& Learning and Director of McMaster University's MacPherson Institute. In 1992, he was recognized as a $3 \mathrm{M}$ National Teaching Fellowship. He is past president of The Society for Teaching and Learning in Higher Education, a national association of Canadian teachers and Vice-President of The International Consortium for Educational Development consisting of 24 member organizations worldwide.

Aadil Ali is a graduate student at the University of Toronto where he is investigating methods to improve lung transplantation. He aspires to enter the field of cardiothoracic surgery. Aadil completed his undergraduate degree at McMaster University specializing in the field of Molecular biology \& Genetics.

John VanMaaren is a PhD Candidate in the Religious Studies Department at McMaster University. He is working on the emergence of early Christianity among the complexities of firstcentury Jewish identities. His plans after graduation are to teach at a university somewhere in North America.

Janette Barrington is an independent research consultant on numerous projects and previous Associate Director of Educational Development at the MacPherson Institute for Leadership at McMaster University.

Ahmad, A., Ali, A., VanMaaren, J., Barrington, J., Merritt, O., \& Ansilio, K.(2017) Partnership in Practice? Implementing Healey's Conceptual Model International Journal for Students as Partners 1(2) 
Olivia Merrit is an MA student at the University of Waterloo studying Clinical Psychology, with research interests in Obsessive Compulsive Disorder (OCD) and anxiety disorders. She hopes to continue her education with PhD studies and aspires to work as a Clinical Psychologist.

Kyle Ansilio is an MA student in Engineering Physics with a focus on Radiation Safety at McMaster University. He completed a BA in Engineering Physics with a specialization in Nuclear Engineering at McMaster University

The order of authors is reflective of contributions in the manuscript preparation.

\section{REFERENCES}

Bovill, C., \& Bulley, C. J. (2011). A model of active student participation in curriculum design: Exploring desirability and possibility. Improving Student Learning (ISL) 18: Global Theories and Local Practices: Institutional, Disciplinary and Cultural Variations., (July), 176-188. Retrieved from http://www.brookes.ac.uk/services/ocsld/books/improving_student_learning/global_theo ries.html

Cook-Sather, A., Bovill, C., \& Felten, P. (2014). Engaging students as partners in learning and teaching: A guide for faculty. San Francisco, CA: Jossey Bass.

Deane, P. (2014). Institutional vision, mission and proposed mandate statement. Unpublished internal document. McMaster University. Retrieved from http://www.mcmaster.ca/vpacademic/documents/SMA-McMaster-March,2014.pdf

Dewey, J. (1933). How we think: A restatement of the relation of reflective thinking to the educative process. Lexington, MA: D.C. Heath.

Ede, L., \& Lunsdord, A. (1990). Singular texts/plural authors: Perspectives on collaborative writing. Carbondale, IL: Southern Illinois University Press.

Felten, P., Bagg, J., Bumbry, M., Hill, J., Hornsby, K., Pratt, M., \& Weller, S. (2013). A call for expanding inclusive student engagement in SoTL. Teaching and Learning in Medicine, 1(2), 63-74. http://dx.doi.org/10.20343/teachlearninqu.1.2.63

Fine, M. A., \& Kurdek, L. A. (1993). Reflections on determining authorship credit and authorship order on faculty-student collaborations. American Psychologist, 48(11), 1141-1147. http://dx.doi.org/10.1037/0003-066X.48.11.1141

Hart, R. (1992). Ladder of participation, children's participation: From Tokenism to citizenship. Innocenti Essays No. 4. Florence, Italy: UNICEF-ICDC.

Healey, M., Flint, A., \& Harrington, K. (2014). Engagement through partnership: Students as partners in learning and teaching in higher education. The Higher Education Academy Report, (July), 1-76. http://dx.doi.org/10.1080/1360144X.2016.1124966

Healey, M., Flint, A., \& Harrington, K. (2016). Students as partners: Reflections on a conceptual model. Teaching \& Learning Inquiry, 4(2), 13 pp. http://dx.doi.org/10.20343/10.20343/teachlearninqu.4.2.3

Hutchings, C., Bartholomew, N., \& Reilly, O. (2013). Differential student engagement: Lessons learned. In C. Nygaard, S. Brand, P. Bartholomew, \& L. Millard (Eds.), Student engagement:

Ahmad, A., Ali, A., VanMaaren, J., Barrington, J., Merritt, O., \& Ansilio, K.(2017) Partnership in Practice? Implementing Healey's Conceptual Model International Journal for Students as Partners 1(2) 
Identity, motivation and community (pp. 125-144) Faringdon: Libri Publishing.

Kuh, G. D., Kinzie, J., Schuh, J., \& Whitt, E. J. (2005). Assessing conditions to enhance educational effectiveness: The Inventory for Student Engagement and Success. San Francisco, CA: Jossey-Bass.

Lave, J., \& Wenger, E. (1991). Situated learning: Legitimate peripheral participation. Learning in Doing, 95, 138. http://dx.doi.org/10.2307/2804509

McDermott, R. (1999). Why information technology inspired but cannot deliver knowledge management. California Management Review, 41(4), 103-117. http://dx.doi.org/10.2307/41166012

McKinney, K., Jarvis, P., Creasey, G., \& Hermann, D. (2010). A range of student voices in the scholarship of teaching and learning. In C. Werder \& M. M. Otis (Eds.), Engaging student voices in the study of teaching and learning (pp. 81-95). Sterling, VA: Stylus.

Mcmillan, D. W., \& Chavis, D. M. (1986). Sense of community: A definition and theory. Journal of Community Psychology, 14, 7-19.

MIIETL. (2015). MIIETL Strategic Plan 2014-19 (2015-16 update). Hamilton.

Robotham, D., \& Julian, C. (2006). Stress and the higher education student: A critical review of the literature. Journal of Further and Higher Education, 30(2), 107-117. http://dx.doi.org/10.1080/03098770600617513

Rudduck, J., \& Fielding, M. (2006). Student voice and the perils of popularity. Educational Review, 58(2), 219-231. http://dx.doi.org/10.1080/00131910600584207

Stake, R. E. (1995). The art of case study research: perspectives on practice. Thousand Oaks, CA: Sage. http://doi.org/10.2307/329758

Summers, P., Pearson, D., Gough, S., \& Siekierski, J. (2013). The effects of student engagement of employing students in professional roles. Faringdon: Libri Publishing.

Taylor, C.A. (2009). Student voice: Theorising power and participation. Pedagogy, Culture \& Society, 17(2), 37-41. http://dx.doi.org/10.1080/14681360902934392

Wenger, E. (1998). Communities of practice: Learning, meaning, and identity. Cambridge: Cambridge University Press.

Ahmad, A., Ali, A., VanMaaren, J., Barrington, J., Merritt, O., \& Ansilio, K.(2017) Partnership in Practice 10 Implementing Healey's Conceptual Model International Journal for Students as Partners 1(2) 